\title{
Rhizobial Microsymbionts of Kamchatka Oxytropis Species Possess Genes of the Type III and VI Secretion Systems, Which Can Affect the Development of Symbiosis
}

\author{
Vera I. Safronova, ${ }^{1+}{ }^{+}$Polina V. Guro, ${ }^{1}$ Anna L. Sazanova, ${ }^{1}$ Irina G. Kuznetsova, ${ }^{1}$ Andrey A. Belimov, ${ }^{1}$ \\ Valentin V. Yakubov, ${ }^{2}$ Elizaveta R. Chirak, ${ }^{1}$ Alexey M. Afonin, ${ }^{1}$ Yuri V. Gogolev, ${ }^{3}$ Evgeny E. Andronov, ${ }^{1}$ \\ and Igor A. Tikhonovich ${ }^{1,4}$ \\ ${ }^{1}$ All-Russia Research Institute for Agricultural Microbiology (ARRIAM), 196608, St.-Petersburg, Sh. Podbelskogo 3, Russian \\ Federation \\ ${ }^{2}$ Federal Scientific Center of the East Asia Terrestrial Biodiversity, Far Eastern Branch of the RAS, 690022, Vladivostok, Ave. \\ 100-let Vladivostoka 159, Russian Federation \\ ${ }^{3}$ Kazan Institute of Biochemistry and Biophysics, FRC Kazan Scientific Center of RAS, 2/31 Lobachevsky St., Kazan 420111, \\ Russian Federation \\ ${ }^{4}$ Saint Petersburg State University, Department of Genetics and Biotechnology, 199034, St.-Petersburg, Universitetskaya Emb. \\ 7/9, Russian Federation
}

Accepted 17 July 2020.

\begin{abstract}
A collection of rhizobial strains isolated from root nodules of the narrowly endemic legume species $O x y$ tropis erecta, $O$. anadyrensis, $O$. kamtschatica, and $O$. pumilio originating from the Kamchatka Peninsula (Russian Federation) was obtained. Analysis of the $16 \mathrm{~S}$ ribosomal RNA gene sequence showed a significant diversity of isolates belonging to families Rhizobiaceae (genus Rhizobium), Phyllobacteriaceae (genera Mesorhizobium, Phyllobacterium), and Bradyrhizobiaceae (genera Bosea, Tardiphaga). A plant nodulation assay showed that only strains belonging to genus Mesorhizobium could form nitrogen-fixing nodules on Oxytropis plants. The strains $M$. loti 582 and M. huakuii 583, in addition to symbiotic clusters, possessed genes of the type III and type VI secretion systems (T3SS and T6SS, respectively), which can influence the host specificity of strains. These strains formed nodules of two
\end{abstract}

Sequences have been deposited to the NCBI GenBank database under accession numbers CP050292 for Tardiphaga robiniae 581, CP050293 to CP050295 for Mesorhizobium loti 582, CP050296 to CP050299 for M. huakuii 583, СР050300 to CP050303 for Phyllobacterium sp. strain 628, CP050304 to CP050308 for Rhizobium lusitanum 629, CP050549 to CP050552 for R. leguminosarum RCAM0610, CP050553 to CP050557 for $R$. leguminosarum RCAM0626, CP050514 to CP050519 for $R$. leguminosarum RCAM1365, CP050562 to CP050566 for $R$. leguminosarum RCAM2802, CP050558 to CP050561 for Sinorhizobium meliloti RCAM1115, and CP050511 to CP050513 for S. meliloti RCAM1750. Rrs sequences can be found under accession numbers MT192879 to MT225791.

\section{${ }^{\dagger}$ Corresponding author: V. I. Safronova; v.safronova@rambler.ru}

Funding: This work was supported by the Russian Science Foundation (grant 16-16-00080 for microbiology, molecular work and pot experiments and grant 17-14-01363 for bioinformatics work). Deposition of strains in the Russian Collection of Agricultural Microorganisms was supported by the Program for the Development and Inventory of Bioresource Collections.

*The $\boldsymbol{e}$-Xtra logo stands for "electronic extra" and indicates there are supplementary materials published online.

The author(s) declare no conflict of interest.

๑) 2020 The American Phytopathological Society types (elongated and rounded) on $O$. kamtschatica roots. We suggest this phenomenon may result from Nod factor-dependent and -independent nodulation strategies. The obtained strains are of interest for further study of the T3SS and T6SS gene function and their role in the development of rhizobium-legume symbiosis. The prospects of using rhizobia having both gene systems related to symbiotic and nonsymbiotic nodulation strategies to enhance the efficiency of plant-microbe interactions by expanding the host specificity and increasing nodulation efficiency are discussed.

Keywords: Kamchatka region, Oxytropis spp., plant-microbe interaction, symbiosis, T3SS, T6SS

The legume genus Oxytropis does not have much agricultural value but forms natural pastures, successfully growing on poor soils of the northern temperate, subarctic, and arctic regions (Ampomah et al. 2017; Ghobakhlou et al. 2015; Hou et al. 2009; Sprent 2001). The Mesorhizobium strains have been identified as the predominant bacteria that nodulate Oxytropis plants, whereas the genera Rhizobium, Sinorhizobium, and Bradyrhizobium have been found as their minor symbionts (Ampomah et al. 2017; Ghobakhlou et al. 2015; Hou et al. 2009; Laguerre et al. 1997; Xu et al. 2013). Among Mesorhizobiumrelated strains, representatives of different species were identified as $M$. amorphae, $M$. temperatum, $M$. mediterraneum, $M$. loti, M. ciceri, and M. gobiense (Han et al. 2008; Hou et al. 2009); however, many isolated strains are still without species definition.

Information about strains isolated from root nodules of Miocene-Pliocene relics $O$. triphylla and $O$. popoviana, which originated from the Baikal Lake region (Siberia), was recently published (Safronova et al. 2017, 2018a and b). It was shown that the rhizobial microsymbionts of these plants belonged to the genera Bosea, Tardiphaga, Phyllobacterium, and Mesorhizobium. Although Bosea and Tardiphaga strains were often found in the root nodules of different legumes, there is no information about their ability to form symbiosis with host plants. It was suggested that they can be present in nodules as carriers of ancestral genes that can contribute to the formation of 
symbiosis and affect its effectiveness (Provorov 2013). The ability of most Phyllobacterium strains to singly induce nodules was also not clearly demonstrated (Mantelin et al. 2006), although representatives of at least two species ( $P$. sophorae and $P$. trifolii) can form effective symbiosis with host plants (Jiao et al. 2015; Valverde et al. 2005). Mesorhizobium-related strains were isolated only from $O$. popoviana nodules and were identified as M. japonicum and M. kowhai species (Safronova et al. 2017, 2018a and b). Previously these rhizobial species were described for Lotus and Sophora nodulating strains, respectively (De Meyer et al. 2016; Martínez-Hidalgo et al. 2016).

Symbiotic systems of legumes possessing a wide range of microsymbionts are promising models for studying the evolution of host specificity, the impact of natural rhizobial diversity on plant growth, and multipartite interactions between all symbiotic partners. In this regard, the aim of this work was to study rhizobial strains isolated from the root nodules of four narrowly endemic Oxytropis species growing in the Kamchatka Peninsula: O. erecta, O. anadyrensis, O. kamtschatica, and
O. pumilio. Particular attention was paid to the phylogeny of the isolated strains and analysis of their symbiotic potential using plant nodulation assays, whole-genome sequencing, and the search for genes (Sym genes as well as the type III, IV, and VI secretion systems [T3SS, T4SS, and T6SS, respectively]) that can affect the development of plant-microbe interactions.

\section{RESULTS AND DISCUSSION}

Isolation of rhizobial strains from $O$. erecta, $O$. anadyrensis, $O$. kamtschatica, and $O$. pumilio plants and their identification by sequencing

\section{the $16 \mathrm{~S}$ ribosomal RNA (rRNA) gene.}

Forty-five rhizobial strains were isolated from Oxytropis species root nodules originating from the Kamchatka Peninsula. The identification of isolates by sequencing the $16 \mathrm{~S}$ rRNA gene showed that they belonged to different species and genera of the order Rhizobiales (Table 1). Only one strain (629) was related to the genus Rhizobium and was identified as $R$. lusitanum (rrs similarity with the type strain $\mathrm{P} 1-7^{\mathrm{T}}$ was

Table 1. Identification of strains isolated from Oxytropis erecta, O. anadyrensis, $O$. kamtschatica, and $O$. pumilio plants by $16 \mathrm{~S}$ ribosomal RNA gene sequencing

\begin{tabular}{|c|c|c|c|c|}
\hline \multirow[b]{2}{*}{ Plant species } & \multirow[b]{2}{*}{$\operatorname{Strain}^{\mathrm{z}}$} & \multicolumn{2}{|c|}{ Similarity with the closest species } & \multirow[b]{2}{*}{ Identification resul } \\
\hline & & Type strain & Identity\% & \\
\hline \multirow[t]{9}{*}{ O. erecta } & $553 \mathrm{a}$ & Bosea vaviloviae Vaf- 18 & 100 & B. vaviloviae \\
\hline & 554 a & Tardiphaga robiniae $\mathrm{R}-45977$ & 99.9 & T. robiniae \\
\hline & 558 & T. robiniae $\mathrm{R}-45977$ & 99.9 & T. robiniae \\
\hline & 559 & Mesorhizobium loti LMG 6125 & 99.8 & M. loti \\
\hline & 561 & T. robiniae $\mathrm{R}-45977$ & 98.6 & Tardiphaga sp. \\
\hline & $563 \mathrm{~b}$ & Phyllobacterium loti S658 & 100 & P. loti \\
\hline & $565 \mathrm{~b}$ & M. loti LMG 6125 & 99.8 & M. loti \\
\hline & 568 & T. robiniae $\mathrm{R}-45977$ & 100 & T. robiniae \\
\hline & 569 & M. loti LMG 6125 & 100 & M. loti \\
\hline \multirow[t]{10}{*}{ O. kamtschatica } & 571 & B. vaviloviae Vaf- 18 & 99.6 & B. vaviloviae \\
\hline & 572 & M. jarvisii ATCC 33669 & 99.9 & M. jarvisii \\
\hline & 576 & T. robiniae $\mathrm{R}-45977$ & 99.9 & T. robiniae \\
\hline & 578 & M. huakuii NBRC 15243 & 100 & M. huakuii \\
\hline & $581 \mathrm{c}$ & T. robiniae $\mathrm{R}-45977$ & 99.9 & T. robiniae \\
\hline & $582 \mathrm{c}$ & M. loti LMG 6125 & 99.9 & M. loti \\
\hline & 583 & M. huakuii NBRC 15243 & 99.7 & M. huakuii \\
\hline & 584 & M. jarvisii ATCC 33669 & 100 & M. jarvisii \\
\hline & $585 \mathrm{~d}$ & B. vaviloviae Vaf-18 & 99.9 & B. vaviloviae \\
\hline & $586 \mathrm{~d}$ & T. robiniae $\mathrm{R}-45977$ & 99.9 & T. robiniae \\
\hline \multirow[t]{8}{*}{ O. anadyrensis } & $589 \mathrm{e}$ & B. vaviloviae Vaf- 18 & 100 & B. vaviloviae \\
\hline & $590 \mathrm{e}$ & T. robiniae $\mathrm{R}-45977$ & 99.9 & T. robiniae \\
\hline & 592 & T. robiniae $\mathrm{R}-45977$ & 99.9 & T. robiniae \\
\hline & 593 & T. robiniae $\mathrm{R}-45977$ & 99.9 & T. robiniae \\
\hline & $594 \mathrm{f}$ & B. vaviloviae Vaf-18 & 100 & B. vaviloviae \\
\hline & $595 \mathrm{f}$ & T. robiniae $\mathrm{R}-45977$ & 99.9 & T. robiniae \\
\hline & 596 & T. robiniae $\mathrm{R}-45977$ & 99.9 & T. robiniae \\
\hline & 597 & T. robiniae $\mathrm{R}-45977$ & 100 & T. robiniae \\
\hline \multirow[t]{18}{*}{ O. pumilio } & 608 & P. myrsinacearum NBRC 100019 & 100 & P. myrsinacearum \\
\hline & 610 & M. jarvisii ATCC 33669 & 99.9 & M. jarvisii \\
\hline & 612 & M. jarvisii ATCC 33669 & 99.9 & M. jarvisii \\
\hline & 613 & B. vaviloviae Vaf- 18 & 99.4 & Bosea sp. \\
\hline & 614 & P. loti S658 & 100 & P. loti \\
\hline & $616 \mathrm{~g}$ & B. vaviloviae Vaf- 18 & 99.7 & B. vaviloviae \\
\hline & $617 \mathrm{~g}$ & M. loti LMG 6125 & 99.8 & M. loti \\
\hline & $623 \mathrm{~h}$ & B. vaviloviae Vaf- 18 & 99.8 & B. vaviloviae \\
\hline & $624 \mathrm{~h}$ & M. jarvisii ATCC 33669 & 99.9 & M. jarvisii \\
\hline & 625 & B. lathyri R-46060 & 99.9 & B. lathyri \\
\hline & $628 \mathrm{i}$ & P. myrsinacearum NBRC 100019 & 99.2 & Phyllobacterium sp. \\
\hline & $629 \mathrm{i}$ & R. lusitanum $\mathrm{P} 1-7$ & 99.6 & R. lusitanum \\
\hline & 631 & M. loti LMG 6125 & 100 & M. loti \\
\hline & 638 & T. robiniae $\mathrm{R}-45977$ & 99.6 & T. robiniae \\
\hline & 643 & T. robiniae $\mathrm{R}-45977$ & 99.8 & T. robiniae \\
\hline & 646 & M. jarvisii ATCC 33669 & 99.9 & M. jarvisii \\
\hline & 648 & M. jarvisii ATCC 33669 & 99.9 & M. jarvisii \\
\hline & 650 & M. qingshengii CCBAU 33460 & 99.9 & M. qingshengii \\
\hline
\end{tabular}

\footnotetext{
${ }^{\mathrm{z}}$ Matching letters indicate pairs of strains isolated from the same nodule.
} 
99.6\%). The greatest genetic diversity was observed for Mesorhizobium-related isolates belonging to four species: M. loti, M. jarvisii, M. huakuii, and M. qingshengii (Table 1; Fig. 1). Strains 559, 565, 569, 582, 617, and 631 belonged to the species $M$. loti $(99.8$ to $100 \%$ rrs similarity with the type strain LMG $6125^{\mathrm{T}}$ ). Isolates 572, 584, 610, 612, 624, 646, and
648 were the closest to the type strain $M$. jarvisii ATCC $33669^{\mathrm{T}}$, with 99.9 to $100 \%$ rrs similarity. Strains 578 and 583 were classified as $M$. huakuii, while strain 650 was assigned to the species $M$. qingshengii (Table 1). None of the Mesorhizobium-related isolates formed a reliable cluster with statistical support more than $95 \%$ (Fig. 1). The species $M$. loti

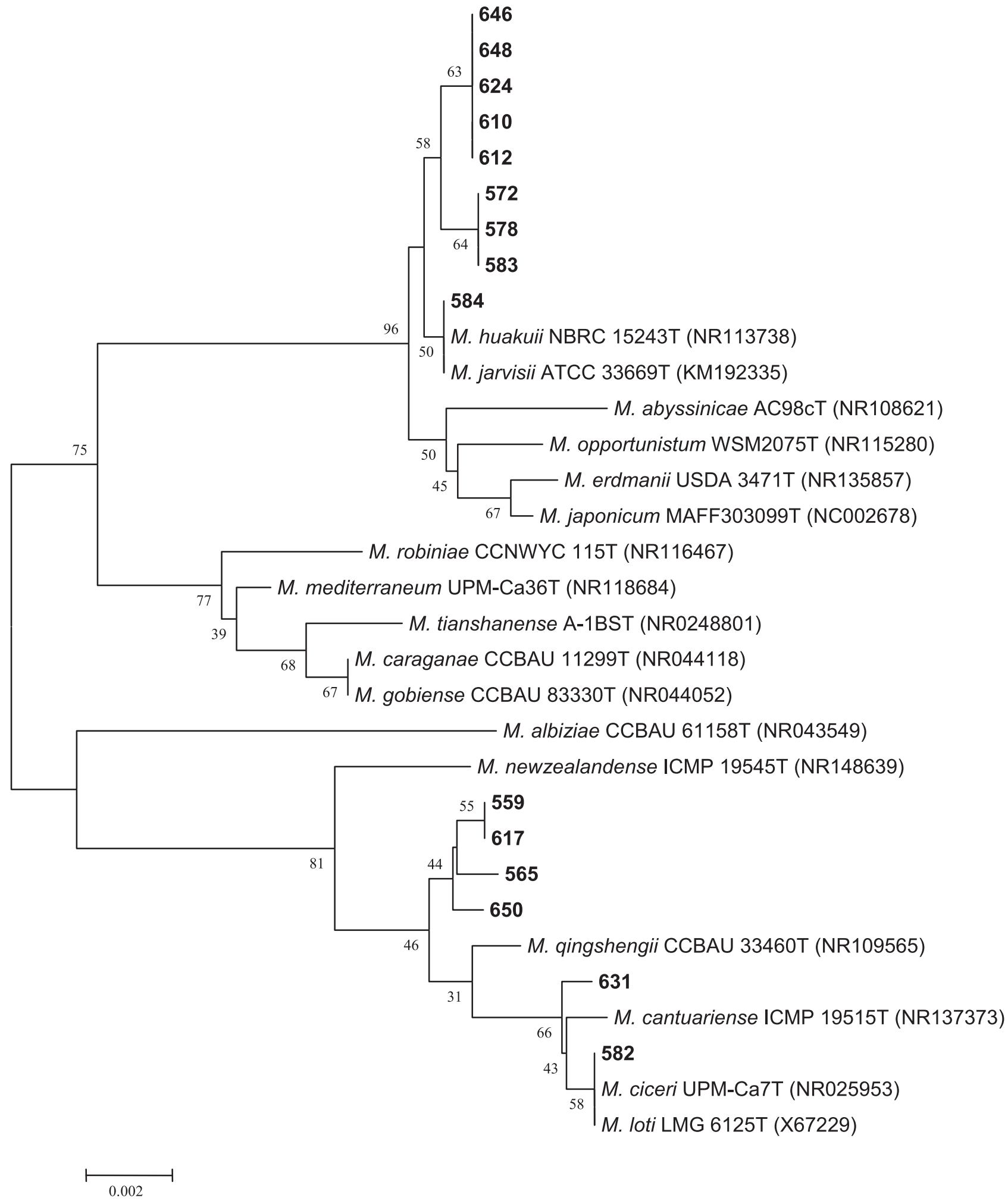

Fig. 1. Phylogenetic tree generated by the neighbor-joining method, using partial $16 \mathrm{~S}$ ribosomal RNA gene sequences (1,400 nt) of the Mesorhizobium-related isolates from Oxytropis erecta, O. kamtschatica, and O. pumilio (in bold) and closely related species. Bootstrap values more than $30 \%$ are given. Type strains are indicated by the letter $\mathrm{T}$. 
has been described for a long time and was isolated from nodules of Lotus corniculatus (Jarvis et al. 1982) as well as the species M. jarvisii (Martínez-Hidalgo et al.. 2015). Representatives of the species $M$. huakuii and $M$. qingshengii are known as specific microsymbionts of the Chinese milk vetch (Astragalus sinicus) from which they were isolated (Chen et al. 1991; Zheng et al. 2013).

Four strains, 563, 608, 614, and 628, were closely related to genus Phyllobacterium (Table 1; Supplementary Fig. S1). Isolate 608 formed the highest supported cluster with the type strain $P$. myrsinacearum NBRC $100019^{\mathrm{T}}(100 \%$ bootstrap support, $100 \%$ rrs similarity), while isolate 628 had only $99.2 \%$ rrs similarity with this type strain and was left without species definition. Strains 563 and 614 had $100 \%$ rrs similarity with type strain $P$. loti $\mathrm{S} 658^{\mathrm{T}}$. It is known that $P$. myrsinacearum strains, originally isolated from leaf nodules of Ardisia plants (Knosel 1984), are also found on the phylloplane and rhizoplane of other plants from the families Myrsinaceae and Rubiaceae (Mergaert et al. 2002). The type strain P. loti $\mathrm{S} 658^{\mathrm{T}}$ was isolated from a Lotus corniculatus nodule in Uruguay (Sánchez et al. 2014).

Strains 553, 571, 585, 589, 594, 616, and 623 had 99.6 to $100 \%$ rrs similarity with the type strain Bosea vaviloviae Vaf $18^{\mathrm{T}}$, while isolate 625 was identified as B. lathyri (Table 1; Supplementary Fig. S2). Previously, B. lathyri (De Meyer and Willems 2012) strains were isolated from root nodules of Lathyrus latifolius plants in Belgium, and the species B. vaviloviae (Safronova et al. 2015) was described for isolates from root nodules of Vavilovia formosa growing in the North Caucasus. Most isolates (14) were identified as Tardiphaga robiniae ( 99.6 to $100 \%$ rrs similarity with the type strain R$45977^{\mathrm{T}}$ ) and the species affiliation of one Tardiphaga-related strain 561 was not determined (Table 1; Supplementary Fig. $\mathrm{S} 3$ ). The species $T$. robiniae were isolated from Robinia pseudoacacia root nodules in Belgium and it is the only member of this genus belonging to the family Bradyrhizobiaceae (De Meyer et al. 2012).

It was noted that pairs of phenotypically and taxonomically different strains were isolated from some nodules of $O$. erecta, $O$. anadyrensis, $O$. kamtschatica, and $O$. pumilio plants (Table 1). The combination of strains in pairs was diverse: Bosea + Tardiphaga, Phyllobacterium + Mesorhizobium, Tardiphaga + Mesorhizobium, Bosea + Mesorhizobium, Phyllobacterium + Rhizobium. The ratio of different strains in the same nodule did not exceed 1:10. Previously, several pairs of rhizobial strains (Bosea + Phyllobacterium and Mesorhizobium + Bradyrhizobium) were isolated from the root nodules of the Miocene-Pliocene relict legumes $O$. triphylla and $O$. popoviana originating from the Baikal Lake region (Safronova et al. 2017; 2018a). Moreover, coinoculation with paired strains significantly accelerated nodule formation and it was suggested that taxonomically different strains of the archaic symbiotic system can be co-microsymbionts infecting the same nodule and resulting in promotion of nodulation process due to complementary sets of symbiotic genes (Safronova et al. 2018a).

Thus, the analysis of the 16S rRNA gene sequence showed a significant species diversity of Oxytropis microsymbionts belonging to three families of the order Rhizobiales: Rhizobiaceae (genus Rhizobium), Phyllobacteriaceae (genera Mesorhizobium and Phyllobacterium), and Bradyrhizobiaceae (genera Bosea and Tardiphaga). It was noted that the spectrum of microsymbionts depended on the host plant. The greatest genetic diversity was observed among rhizobial isolates of the species O. pumilio, while only Bosea and Tardiphaga strains were isolated from $O$. anadyrensis nodules. Among the isolated strains, both typical microsymbionts of legumes belonging to genera Mesorhizobium and Rhizobium were present. Among atypical strains, only certain species possess nodulating ability (genus Phyllobacterium) or may be present in nodules but do not form them (genera Tardiphaga and Bosea). Thus, a number of individual strains and pairs of taxonomically different bacteria in various combinations were isolated from nodules of the studied Oxytropis plants, demonstrating high variability of microsymbionts and low symbiosis specificity of these host plants.

\section{Plant nodulation assays.}

The plant nodulation tests were performed on $O$. erecta, $O$. kamtschatica, and $O$. pumilio plants with the participation of some isolated strains representing different rhizobia genera (Bosea, Tardiphaga, Mesorhizobium, Phyllobacterium, and Rhizobium [Table 1]). Four different variants of joint inoculation with pairs of strains isolated from the same nodule were also studied (B. vaviloviae $553+T$. robiniae 554 , P. loti $563+$ M. loti 565, T. robiniae $581+$ M. loti 582, Phyllobacterium sp. strain $628+R$. lusitanum 629). The results of preliminary and representative tests are presented in Supplementary Table S1 and Table 2, respectively. No nodules were formed on plants inoculated with isolates of the genera Bosea, Tardiphaga, Phyllobacterium, and Rhizobium. At the same time, most strains of the genus Mesorhizobium (M. jarvisii, M. loti, and M. huakuii) formed nitrogen-fixing symbiosis. The nitrogen-fixing activity of the strains was more associated with the host plant than with the bacterial species. The maximum parameter, nanomoles $\mathrm{C}_{2} \mathrm{H}_{4}$ per nodule per hour $\left(\mathrm{nmol} \mathrm{C}_{2} \mathrm{H}_{4}\right.$ nodule $^{-1} \mathrm{~h}^{-1}$ ), was possessed by the strains M. jarvisii 572 and M. huakuii 583 in symbiosis with $O$. kamtschatica plants. Inoculation led to a significant increase in plant biomass only in these two variants (Table 2). The symbiosis with $O$. pumilio plants was less active. In the coinoculations, the pair of strains $B$. vaviloviae $553+T$. robiniae 554 did not lead to the appearance of nodules, while the combination of strains $P$. lot $i$ $563+M$. loti 565 did not change the symbiotic parameters (number of nodules, plant biomass, and nitrogen fixation) compared with strain $M$. loti 565. After coinoculation with strains $T$. robiniae $581+M$. loti 582 , a significant decrease in the parameter nmol $\mathrm{C}_{2} \mathrm{H}_{4}$ plant $^{-1} \mathrm{~h}^{-1}$ was observed as compared with the mono-inoculation with the strain $M$. loti 582. However, a decrease in this parameter occurred as there tended to be fewer nodules (Table 2). The most interesting results were that single-strain inoculations of Phyllobacterium sp. strain 628 and $R$. lusitanum 629 did not nodulate $O$. pumilio plants but their coinoculation formed inactive nodules.

Pictures of nodules obtained in the representative plant nodulation test are shown in Figure 2. Strains of the genus Mesorhizobium formed single, slightly pinkish or pink elongated nodules on plants of all Oxytropis species. Nodules formed by the strains $M$. jarvisii 572 and M. huakuii 583 on $O$. kamtschatica plants had an intense pink color, which correlated with their high nitrogen fixation (Fig. $2 \mathrm{C} 1$ and $\mathrm{C} 2$ ). In mono-inoculations with the strains $M$. loti 582 and $M$. huakuii 583 , in addition to elongated nodules, the formation of atypical rounded nodules was noted (Fig. $2 \mathrm{C} 2$ to $\mathrm{C} 5$ ). These nodules retained their shape during the experiment and were bright yellow or orange. A representative of the rounded nodules that were observed on $O$. pumilio plants in the coinoculation with strains Phyllobacterium sp. strain $628+R$. lusitanum 629 is shown in Figure 2B3.

Nodules obtained in some mono- and coinoculations were studied for the presence of bacteria. Strains M. loti 582 and M. huakuii 583 were found in both elongated and rounded nodules formed in mono-inoculations. The ratio of bacteria in nodules obtained in the coinoculations was approximately 1 to 10 for strains $P$. loti 563 and M. loti 565 and 10 to 1 for strains T. robiniae 581 and $M$. loti 582 , respectively. Nodules formed in 
the variant Phyllobacterium sp. strain $628+R$. lusitanum 629 contained none of the introduced bacteria.

\section{Whole-genome sequencing of the selected isolates.}

To obtain whole-genome sequences, five strains were selected: the non-nodulating strain $T$. robiniae 581 , strains $M$. loti 582 and $M$. huakuii 583, forming elongated and rounded nodules on $O$. kamtschatica plants, and the pair Phyllobacterium sp. strain 628 and $R$. lusitanum 629, which formed only rounded nodules and only in the coinoculation (Table 2; Fig. 2). The search results for the symbiotic fix, nif, nod, noe, and nol genes are presented in Table 3 . It was shown that strains $M$. loti 582 and $M$. huakuii 583 possessed a set of symbiotic genes necessary for the formation of effective symbiosis and were grouped into clusters. In contrast, strain $T$. robiniae 581 possessed only a reduced number of fix genes, while Phyllobacterium sp. strain 628 and $R$. lusitanum 629 had only individual symbiotic genes, which obviously did not participate in the formation of nodules.

The presence of two clusters of fix genes in strains $T$. robiniae 581 and M. loti 582 was noteworthy. Strain M. loti 582, in addition to cluster 1 containing all the necessary nitrogen fixation genes (fixXCBANOQPGHIS), had a cluster 2 with fewer genes (fixKNOQPGHIS). The strain $T$. robiniae 581 did not possess fix $A B C X$ genes, which play a central role in nitrogenase functioning, but had a "long" cluster 2 (fixKNOQPGHS) and a "short" cluster 3 (fixNOQPI). Since the strains T. robiniae 581 and $M$. loti 582 were isolated from the same nodule, we studied the intra- and interstrain similarity between fix gene copies of all these clusters. It turned out that the interstrain homology between the nucleotide sequences of the corresponding gene copies was below $70 \%$ (data not shown), which indicates the absence of horizontal transfer of these genes between two strains localized in the same nodule. Percentages of the intrastrain similarity between the gene copies present in different
Fix clusters of strains $T$. robiniae 581 and $M$. loti 582 are shown in Supplementary Table S2. It was demonstrated that the level of similarity between copies of most fix genes was quite high (more than $80 \%$ nucleotide and protein identity) in strain M. loti 582. At the same time, the gene copies of Fix clusters 2 and 3 had a similarity level of less than $70 \%$ (Supplementary Table S2) in strain T. robiniae 581. The genes within Fix cluster 2 had the highest percentage of similarity with representatives of genus Tardiphaga, whereas the genes of Fix cluster 3 were closest to the strain Oligotropha carboxidovorans (data not shown), which is not a known nitrogen fixator but is closely related to Nitrobacter hamburgensis (Paul et al. 2011). Therefore, it can be concluded that, in strain T. robiniae 581, Fix gene clusters 2 and 3 were obtained from different microbial sources.

In addition to symbiotic genes, a search was made for genes of T3SS, T4SS, and T6SS involved in bacterial virulence due to secretion of broad classes of effector proteins, cytotoxins, lysozymes, lipoproteins, and factors of adherence to epithelial cells and the penetrating system, such as pilus formation, conjugation, protein translocation (Cascales and Christie 2003; Notti and Stebbins 2016; Okazaki et al. 2016; Russell et al. 2014). It is known that these secretion systems in rhizobia can affect the host specificity of strains and determine the number of nodules formed (Nelson and Sadowsky 2015). The T3SS and T4SS have an important role in suppressing the plant immune response along with rhizobial surface polysaccharides (Masson-Boivin et al. 2009). It was shown that deletions of the T3SS or the T4SS had both positive and negative effect on symbiosis (Sugawara et al. 2013; Tampakaki 2014). For example, the partial deletion of vir genes (T4SS) in M. loti R7A led to a decrease in the number of nodules on Lotus corniculatus plants (Hubber et al. 2004). However, deletion of the T4SS allowed the R7A strain to nodulate Leucaena leucocephala, in contrast to the wild-type strain that formed only uninfected tumor-like structures on this plant species. The T6SS is

Table 2. Effects of mono- and coinoculation of Oxytropis erecta, O. kamtschatica and O. pumilio plants with the isolated strains representing different rhizobia genera in the gnotobiotic plant nodulation assay ${ }^{\mathrm{y}}$

\begin{tabular}{|c|c|c|c|c|c|c|}
\hline \multirow[b]{2}{*}{ Host plant } & \multicolumn{2}{|l|}{ Treatment } & \multirow[b]{2}{*}{$\mathbf{N N}$} & \multirow[b]{2}{*}{ PB } & \multicolumn{2}{|c|}{ Nitrogen fixation $^{z}$} \\
\hline & Bacterial species & Strain & & & Plant & Nodule \\
\hline \multirow[t]{8}{*}{ O. erecta } & Bosea vaviloviae & 553 & 0 & $92.4 \pm 10 \mathrm{a}$ & 0 & 0 \\
\hline & Tardiphaga robiniae & 554 & 0 & $87.4 \pm 9 \mathrm{a}$ & 0 & 0 \\
\hline & B. vaviloviae $+T$. robiniae & $553+554$ & 0 & $80.4 \pm 8 \mathrm{a}$ & 0 & 0 \\
\hline & Mesorhizobium loti & 559 & $6.6 \pm 2.0 \mathrm{a}$ & $97.0 \pm 10 \mathrm{a}$ & $770 \pm 240 \mathrm{a}$ & $117 \pm 35 a$ \\
\hline & Phyllobacterium loti & 563 & 0 & $77.5 \pm 20 \mathrm{a}$ & 0 & 0 \\
\hline & M. loti & 565 & $8.0 \pm 2.0 \mathrm{a}$ & $81.9 \pm 16 \mathrm{a}$ & $1228 \pm 153 \mathrm{a}$ & $154 \pm 14 a$ \\
\hline & P. loti + M. loti & $563+565$ & $4.3 \pm 0.7 \mathrm{a}$ & $82.4 \pm 8 \mathrm{a}$ & $928 \pm 211 \mathrm{a}$ & $216 \pm 43 a$ \\
\hline & Control without inoculation & & 0 & $109.7 \pm 14 \mathrm{a}$ & 0 & 0 \\
\hline \multirow[t]{7}{*}{ O. kamtschatica } & M. jarvisii & 572 & $2.3 \pm 0.6 \mathrm{a}$ & $95.0 \pm 8 \mathrm{~b}$ & $1408 \pm 29 \mathrm{c}$ & $612 \pm 11 c$ \\
\hline & T. robiniae & 581 & 0 & $70.8 \pm 10 \mathrm{ab}$ & 0 & 0 \\
\hline & M. loti & 582 & $6.0 \pm 2.3 \mathrm{bc}$ & $74.0 \pm 19 \mathrm{ab}$ & $927 \pm 98 b$ & $155 \pm 15 \mathrm{~b}$ \\
\hline & T. robiniae $+M$. loti & $581+582$ & $3.4 \pm 1.5 \mathrm{ab}$ & $54.2 \pm 13 \mathrm{a}$ & $443 \pm 90 \mathrm{a}$ & $130 \pm 21 \mathrm{~b}$ \\
\hline & M. huakuii & 583 & $1.0 \pm 0.5 \mathrm{a}$ & $76.5 \pm 2 \mathrm{ab}$ & $970 \pm 10 b$ & $970 \pm 10 \mathrm{~d}$ \\
\hline & M. jarvisii & 584 & $8.0 \pm 2.1 \mathrm{c}$ & $103.3 \pm 6 b$ & $273 \pm 85 a$ & $34 \pm 10 \mathrm{a}$ \\
\hline & Control without inoculation & & 0 & $74.4 \pm 9 \mathrm{ab}$ & 0 & 0 \\
\hline \multirow[t]{9}{*}{ O. pumilio } & M. jarvisii & 610 & $5.0 \pm 0.1 \mathrm{~b}$ & $45.0 \pm 10 \mathrm{a}$ & $450 \pm 10 \mathrm{c}$ & $90 \pm 2 b$ \\
\hline & M. jarvisii & 612 & $1.5 \pm 0.3 \mathrm{a}$ & $36.3 \pm 8 \mathrm{a}$ & $37 \pm 12 \mathrm{a}$ & $25 \pm 7 a$ \\
\hline & B. vaviloviae & 616 & 0 & $36.7 \pm 6 \mathrm{a}$ & 0 & 0 \\
\hline & M. loti & 617 & $4.0 \pm 1.6 \mathrm{ab}$ & $40.3 \pm 5 \mathrm{a}$ & $115 \pm 32 \mathrm{a}$ & $29 \pm 6 a$ \\
\hline & Phyllobacterium sp. & 628 & 0 & $45.3 \pm 7 \mathrm{a}$ & 0 & 0 \\
\hline & Rhizobium lusitanum & 629 & 0 & $40.3 \pm 5 \mathrm{a}$ & 0 & 0 \\
\hline & Phyllobacterium sp. strain $628+R$. lusitanum & $628+629$ & $1.5 \pm 0.4 \mathrm{a}$ & $42.7 \pm 5 \mathrm{a}$ & 0 & 0 \\
\hline & M. loti & 631 & $1 \pm 0.3 \mathrm{a}$ & $26.0 \pm 9 \mathrm{a}$ & $29 \pm 6 b$ & $29 \pm 6 a$ \\
\hline & Control without inoculation & & 0 & $34.8 \pm 4 \mathrm{a}$ & 0 & 0 \\
\hline
\end{tabular}

\footnotetext{
${ }^{y}$ The data is shown as mean \pm standard error of one representative experiment $(n=5)$. Different letters show significant differences between treatments (least significant difference test, $P<0.05$ ). $\mathrm{NN}=$ number of nodules (per plant), $\mathrm{PB}=$ plant biomass (milligrams of fresh weight per plant).

${ }^{\mathrm{z}}$ Shown as nanomoles $\mathrm{C}_{2} \mathrm{H}_{4}$ per plant or nodule per hour.
} 
among the least-studied secretion system involved in protein translocation. The sequence for the T6SS has been found in five different species of rhizobia ( $R$. leguminosarum, Bradyrhizobium japonicum, M. loti, Sinorhizobium saheli, and S. fredii), but their role in symbiosis is still not well-understood (Bingle et al. 2008; Sugawara et al. 2013). It was previously shown that strains M. kowhaii Ach-343 and M. japonicum Opo-235, isolated from nodules of relict legumes Astragalus chorinensis and Oxytropis popoviana, respectively, in addition to Sym genes had a representative set of T6SS genes (icmF, tssABCEGJKL, tagFH, $\operatorname{VgrG}, \operatorname{vas} A, H c p$ and $\operatorname{clp} V$ ). These strains demonstrated a wide range of host specificity, including species of different legume genera from tribes Galegeae and Trifolieae (genera Astragalus, Oxytropis, Glycyrrhiza, Medicago and Trifolium) and the presence of both strains in the same nodules and plant cells of Glycyrrhiza uralensis was accompanied by a significant increase in the number of nodules and plant biomass (Safronova et al. 2019).

Search results for genes of the T3, T4, and T6 secretion systems in strains $T$. robiniae 581, M. loti 582, M. huakuii 583, Phyllobacterium sp. strain 628, and R. lusitanum 629 are presented in Table 4 . The whole genomes of six commercial rhizobia strains used for inoculation of vetches, clovers, and alfalfa were studied as reference sequences: $R$. leguminosarum
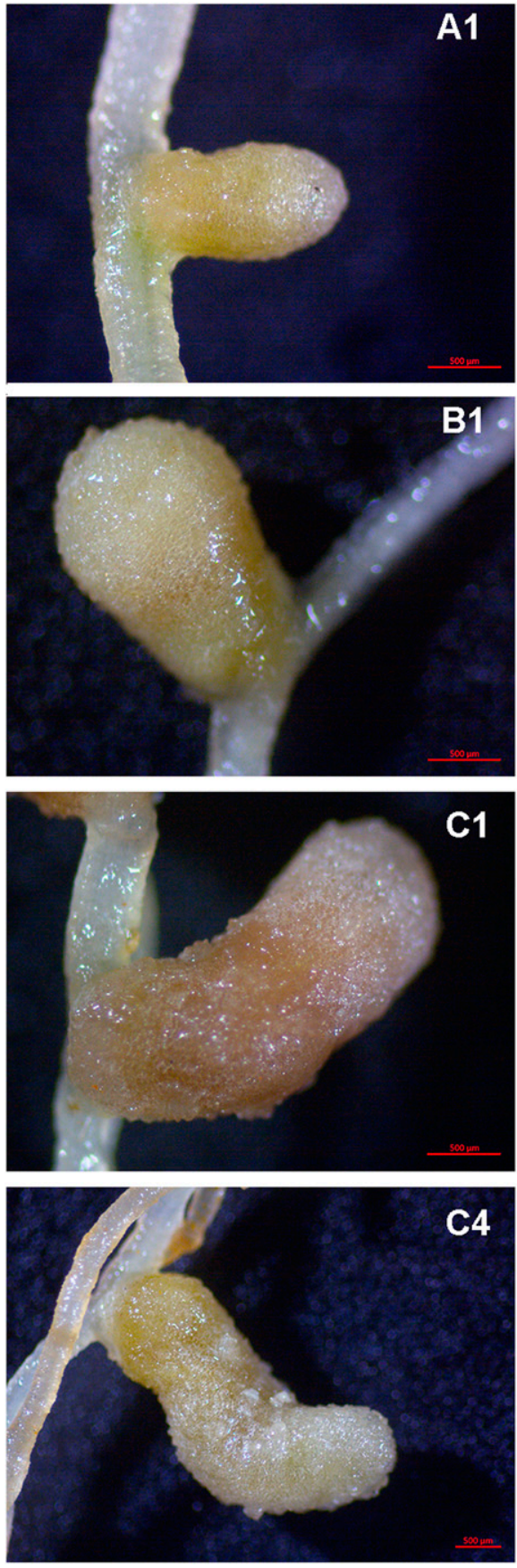
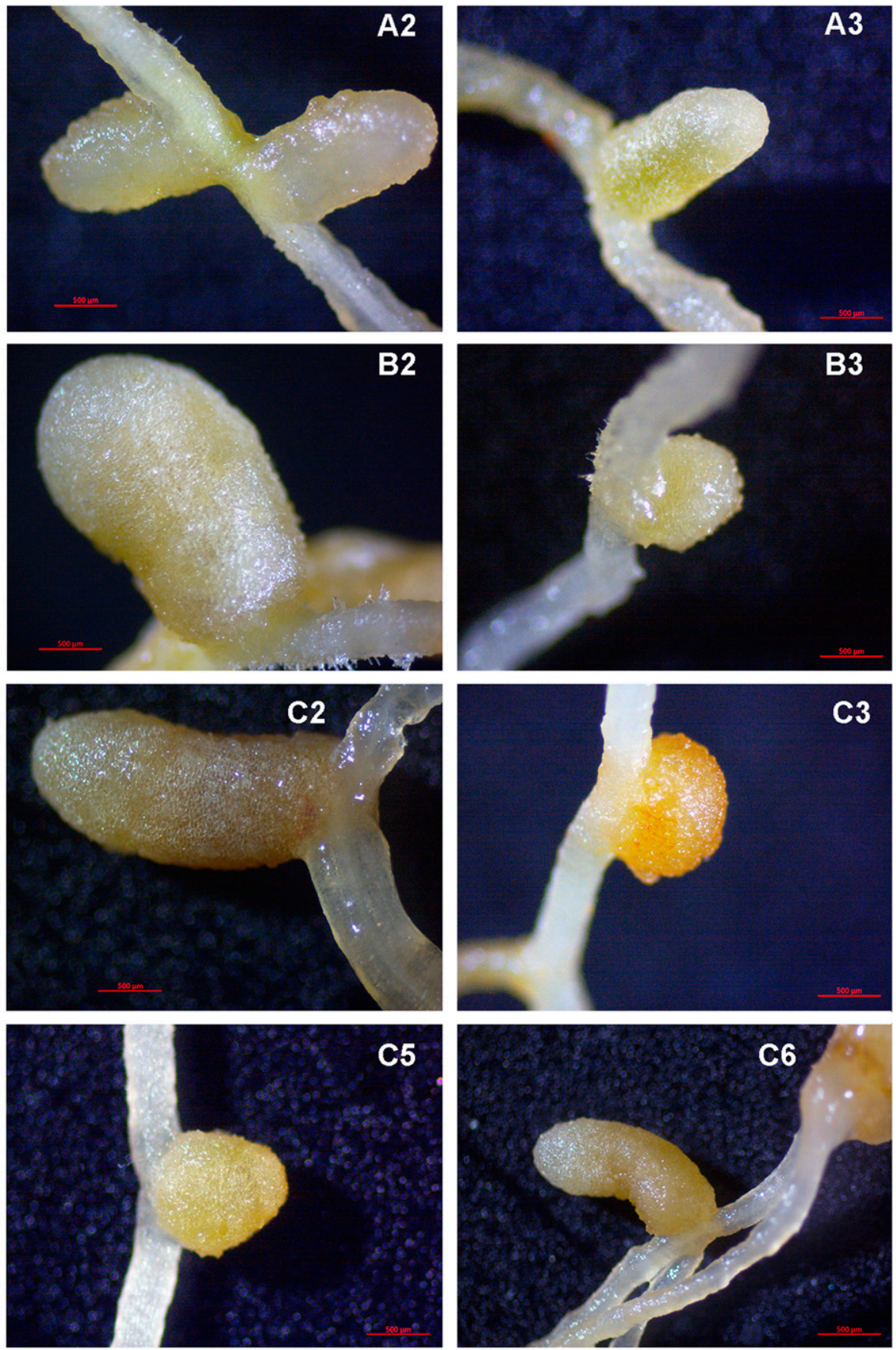

Fig. 2. Root nodules formed in the gnotobiotic plant nodulation assay by the strains isolated from Oxytropis erecta, $O$. kamtschatica, and $O$. pumilio in the variants of mono- and coinoculation. Plant species: A to C, O. erecta, O. pumilio, and $O$. kamtschatica, respectively. Inoculation treatment: Mesorhizobium loti 559 (A1), M. loti 565 (A2), Phyllobacterium loti 563 + M. loti 565 (A3), M. jarvisii 610 (B1), M. loti 617 (B2), Phyllobacterium sp. strain $628+$ Rhizobium lusitanum 629 (B3), M. jarvisii 572 (C1), M. huakuii 583 (C2 and C3, elongated and rounded nodules, respectively), M. loti 582 (C4 and C5, elongated and rounded nodules, respectively), and Tardiphaga robiniae $581+$ M. loti 582 (C6). Scale bar $=500 \mu \mathrm{m}$. 
RCAM0610, RCAM0626, RCAM1365, and RCAM2802 and S. meliloti RCAM1115 and RCAM1750. It was shown that, among isolates from genus Oxytropis, strain T. robiniae 581 possessed only three T4SS genes (virB4, virB11, virB10), strain Phyllobacterium sp. strain 628, in addition to ten virB genes, had gene $c l p V 1$ of T6SS, although it was split into two parts. Strain $R$. lusitanum 629, in addition to the T4SS, had T3SS genes (region $y 4 y B-y 4 x M$ ), while strains $M$. loti 582 and $M$. huakuii 583 possessed a significant set of genes for all three secretion systems (Table 4). At the same time, only virB genes of the T4SS were detected in the four commercial strains (RCAM0610, RCAM1365, RCAM1115, and RCAM1750), and no T3SS, T4SS, or T6SS genes were detected in the two remaining strains, RCAM0626 and RCAM2802.

Thus, it can be stated that three of five strains isolated from the Kamchatka Oxytropis species have a significantly larger set of secretion system genes compared with the six commercial rhizobial strains used as reference. We propose that these genes can affect the host specificity and the formation of symbiosis with the studied Oxytropis species. The question remains whether the ability of strains M. loti 582 and M. huakuii 583 to form nodules of two types on $O$. kamtschatica plants (typical elongated and atypical rounded) is associated with the presence of the T3SS or T6SS genes. It is known that the T3SS secretion system allows some Bradyrhizobium strains with no common nodABC genes (for example strains STM3809, ORS285, ORS375, STM3847, STM4509, STM4523, ORS278, and BTAi1) nodulating the leguminous plant Aeschynomene indica independently of Nod factors (NF) by crack entry (Bonaldi et al. 2011; Mornico et al. 2012; Okazaki et al. 2016). Therefore, it can be assumed that the development of symbiosis by strains simultaneously possessing gene systems for NFdependent and NF-independent nodulation can occur in two ways: i) by the infection thread formation and ii) by the direct

Table 3. Presence of symbiotic genes in the strains isolated from Oxytropis kamtschatica and $O$. pumilio plants and representing different rhizobia genera ${ }^{\mathrm{z}}$

\begin{tabular}{|c|c|c|c|c|c|}
\hline \multirow[b]{2}{*}{ Symbiotic genes } & \multicolumn{5}{|c|}{ Strain } \\
\hline & T. robiniae 581 & M. loti 582 & M. huakuii 583 & $\begin{array}{l}\text { Phyllobacterium } \\
\text { sp. strain } 628\end{array}$ & R. lusitanum 629 \\
\hline Fix cluster 1 & - & XCBA NOQPGHIS & XCBA SIHGQPON & - & - \\
\hline Fix cluster 2 & $K N O Q P G H S$ & KNOQPGHIS & - & - & - \\
\hline Fix cluster 3 & $N O Q P I$ & - & - & - & - \\
\hline fixBA & + & + & + & + & + \\
\hline fixR & + & - & - & - & - \\
\hline Nif cluster & - & A TZBA SVW Q HDKENX & HDKENX A TZBA SVW $Q$ & - & - \\
\hline nifL & + & - & - & - & - \\
\hline$n i f R$ & + & - & - & + & + \\
\hline nifs & + & - & - & - & + \\
\hline nifU & - & - & - & - & + \\
\hline Nod cluster & - & $D$ AFEGBCIJHPQ TM & QPHJICBGEFA D MT & - & - \\
\hline $\operatorname{nod} B$ & + & - & - & - & - \\
\hline $\operatorname{nod} G$ & + & - & - & + & + \\
\hline $\operatorname{nod} M$ & + & - & - & + & + \\
\hline $\operatorname{nod} N$ & - & - & + & + & - \\
\hline $\operatorname{nod} P$ & - & + & - & - & + \\
\hline $\operatorname{nod} Q$ & + & - & + & + & + \\
\hline $\operatorname{nod} \bar{T}$ & - & - & - & - & + \\
\hline noeK & - & - & - & - & + \\
\hline Nol cluster & - & VUTBWX & XWBTUV & - & - \\
\hline nolL like & + & + & + & + & + \\
\hline
\end{tabular}

${ }^{\mathrm{z}}$ Strains Tardiphaga robiniae 581, Mesorhizobium loti 582 and M. huakuii 583 were isolated from $O$. kamtschatica and Phyllobacterium sp. strain 628 and Rhizobium lusitanum 629 from O. pumilio.

Table 4. Presence of type III, IV, and VI secretion system (T3SS, T4SS, and T6SS, respectively) genes in the strains isolated from Oxytropis kamtschatica and O. pumilio plants ${ }^{\mathrm{y}}$

\begin{tabular}{|c|c|c|c|c|}
\hline \multirow[b]{2}{*}{ Bacterial species } & \multirow[b]{2}{*}{ Strain } & \multicolumn{3}{|c|}{ Secretion system } \\
\hline & & T3SS & T4SS & T6SS \\
\hline \multirow[t]{4}{*}{ R. leguminosarum } & RCAM0610 & - & $\operatorname{virB1} 1,2,3,4,5,6,8,9,10,11$ & - \\
\hline & RCAM0626 & - & - & - \\
\hline & RCAM1365 & - & $\operatorname{vir} B 1,2,3,4,5,6,8,9,10,11$ & - \\
\hline & RCAM2802 & - & - & - \\
\hline \multirow[t]{2}{*}{ S. meliloti } & RCAM1115 & - & $\operatorname{vir} B 1,2,3,4,5,6,7,8,9,10,11$ & - \\
\hline & RCAM1750 & - & $\operatorname{vir} B 1,2,3,4,5,6,8,9,10,11$ & - \\
\hline T. robiniae & 581 & - & $\operatorname{vir} B 4,11 ; 10$ & - \\
\hline M. loti & 582 & $\begin{array}{c}\text { rhcV; } \text { rhcUTSRQNL, nolUTW, } \\
\text { nopX, rhcC, ttsI }\end{array}$ & $\operatorname{virB1}, 2,3,4,5,6,8,9,10,11$ & $\begin{array}{l}\text { clpVI, tss } A B C, \text { hcp } 1, \text { tss } E F G, \operatorname{tag} H, \\
\text { tssJKL, icm } F, \operatorname{tag} F, v g r G \text {, FHA domain, } \\
\text { dot } U \text { family, icm } F \text { fragment }\end{array}$ \\
\hline M. huakuii & 583 & $\begin{array}{l}\text { ttsI, rhcC, nopX, nolWTU, } \\
\text { rhcLNQRSTU; rhcV }\end{array}$ & $\operatorname{virB1}, 2,3,4,5,6,8,9,10,11$ & 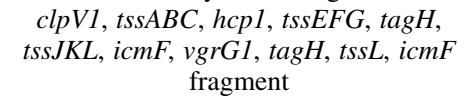 \\
\hline Phyllobacterium sp. & 628 & - & $\operatorname{virB1} 1,2,3,4,5,6,8,9,10,11$ & $\operatorname{clp} V 1^{\mathrm{z}}$ \\
\hline R. lusitanum & 629 & region $y 4 y B-y 4 x M$ & $\operatorname{virB1} 1,2,3,4,5,6,8,9,10,11$ & - \\
\hline
\end{tabular}


penetration of bacteria through the host cell wall. This possibility was previously shown for Bradyrhizobium sp. strain ORS285, which used NF-dependent strategy for nodulation of A. afraspera plants and NF-independent strategy for nodulation of $A$. indica (Bonaldi et al. 2011). In that case, no nodule formation differing in morphology was detected on $A$. indica. However, development of outgrowths at the top of nodules was observed on A. afraspera plants inoculated with strain ORS285. These outgrowths were probably derived from outer cortical cells and were filled with undifferentiated bacteria that did not release into the host cytoplasm. A possible reason for the appearance of various structures in the course of nodule organogenesis on the $A$. afraspera roots is the availability of different nodulation strategies in Bradyrhizobium sp. strain ORS285.

In $R$. lusitanum 629, which has no common nodABC genes needed for nodule formation, a $y 4 y B-y 4 x M$ region similar to that of strain $S$. fredii NGR234 was found (Table 4). S. fredii NGR234 has an exceptionally broad host range and is able to nodulate more than 112 genera of legumes (Pueppke and Broughton 1999; Streit et al. 2004). It was shown that, in $S$. fredii strains, the rhcI (Rhizobium-conserved) gene family of the T3SS contains a group of genes $y 4 y B, y 4 y A, y 4 x P, y 4 x O$, $y 4 x N$, and $y 4 x M$ that may be related to the secretion of nodulation outer proteins called Nops (Krishnan et al. 2003; Weidner et al. 2012). Although it was shown that expression of $y 4 y A$, $y 4 y B$, and $y 4 x P$ is flavonoid-dependent (Jiang and Krishnan 2000; Streit et al. 2004), the role of this group of genes in rhizobial symbiosis remains unknown. Our results showed that $R$. lusitanum 629 was not able to form nodules or nodule-like structures on $O$. pumilio plants. However, in the coinoculation with Phyllobacterium sp. strain 628, which was isolated from the same nodule, the formation of nonfixing, rounded nodules on the roots of the host plant was observed (Table 2; Supplementary Table S1; Fig. 2). The reason for this phenomenon is difficult to explain, since Phyllobacterium sp. strain 628 has neither common sym genes nor T3SS or T6SS genes, except for the $c l p V 1$ gene (Tables 3 and 4). Perhaps other genes present in Phyllobacterium sp. strain 628 and R. lusitanum 629 and performing complementary functions allow the formation of atypical nodules in the coinoculation. Such factors may be, for example, surface polysaccharides involved in symbiosis specificity, namely, lipopolysaccharides, extracellular polysaccharides and capsular poylsaccharides (Nelson and Sadowsky 2015; Streit et al. 2004).

Thus, the obtained results showed very high variability among the strains isolated from the narrow endemic species of Oxytropis plants originating from Kamchatka. These strains may be useful for the study of functions of the T3SS, T4SS, and T6SS genes and their role in the development of rhizobialegume symbiosis. The rhizobial strains having gene systems for both symbiotic and nonsymbiotic nodulation may be also applied for enhancing the efficiency of plant-microbe interactions by expanding host specificity and increasing the efficiency of nodulation of agricultural legumes.

\section{MATERIALS AND METHODS}

\section{Isolation of rhizobial strains from the root nodules.}

Rhrizobial strains were isolated from root nodules of four narrowly endemic species of the legume genus Oxytropis (O. erecta, $O$. anadyrensis, $O$. kamtschatica and $O$. pumilio) originating from the Kamchatka Peninsula (Russian Federation). The standard method was used for isolation of bacteria from surface-sterilized single nodules (Novikova and Safronova 1992). The isolates were grown at $28^{\circ} \mathrm{C}$ on the modified yeast extract mannitol agar (Vincent 1970) supplemented with $0.5 \%$ succinate (Safronova et al. 2015). One or two taxonomically different strains were isolated from the same nodule. All isolates are deposited in the Russian Collection of Agricultural Microorganisms (RCAM) and are stored at $-80^{\circ} \mathrm{C}$ in the automated Tube Store (Liconic Instruments).

\section{Identification of isolates by the sequencing of the $16 \mathrm{~S}$ rRNA gene.}

For identification of all isolates, the following PCR primers were used: fD1 (5'-AGAGTTTGATCCTGGCTCAG-3') and rD1 (5'-CTTAAGGAGGTGATCCAGCC-3') for an approximately 1,400-bp segment of the 16S rRNA ( $r r s)$ gene (Weisburg et al. 1991). PCR was performed in $25-\mu 1$ reaction mixtures containing $150 \mu \mathrm{M}$ dNTPs (Promega), $5 \mathrm{pmol}$ of each primer, $1 \mathrm{U}$ of Taq polymerase (Helicon) and 50 to $100 \mathrm{ng}$ of purified template DNA. PCR conditions for amplification of the $16 \mathrm{~S}$ rRNA gene were as follows: initial denaturation at $95^{\circ} \mathrm{C}$ for $3 \mathrm{~min} 30 \mathrm{~s} ; 35$ cycles of denaturation at $94^{\circ} \mathrm{C}$ for 1 min $10 \mathrm{~s}$, annealing at $56^{\circ} \mathrm{C}$ for $40 \mathrm{~s}$, and extension at $72^{\circ} \mathrm{C}$ for $2 \mathrm{~min} 10 \mathrm{~s}$; final extension at $72^{\circ} \mathrm{C}$ for $6 \mathrm{~min} 10 \mathrm{~s}$. Electrophoresis was carried out with $1 \%$ agarose gel (Invitrogen) in Tris-acetateEDTA. A 100-bp GeneRuler and Lambda DNA/HindIII markers (Fermentas) were used for sizing and approximate quantification of DNA fragments. Purification of the PCR products was usually performed by using PureLink Quick kit (Invitrogen) according to manufacturer guidance. The direct sequencing of PCR products was performed by an ABI PRISM $3500 x 1$ genetic analyzer (Applied Biosystems). The sequences were compared with related sequences of the type strains available in the GenBank database, using BLAST analysis (basic logical alignment search tool) at the National Center for Biotechnology Information (NCBI). Rrs dendrograms were constructed using the neighbor-joining method in MEGA 6.0 software package (Tamura et al. 2011). The evolutionary distances were computed using the maximum composite likelihood method. Bootstrap analysis with 1,000 replicates was performed to estimate the support of clusters.

\section{Plant nodulation assays.}

Seeds of $O$. erecta, $O$. kamtschatica, and $O$. pumilio plants were surface-sterilized by $\mathrm{H}_{2} \mathrm{SO}_{4}$ for $15 \mathrm{~min}$, were washed with sterile tap water, and were germinated on filter paper in Petri dishes at $25^{\circ} \mathrm{C}$ in the dark for 4 days. The $O$. anadyrensis species was not used, due to lack of seeds. Germinated seedlings were transferred to 50-ml glass test tubes (two seedlings per test tube) that contained $3 \mathrm{~g}$ of sterile vermiculite. In each tube, $6 \mathrm{ml}$ of the nutrient solution [grams per liter: $1.0 \mathrm{~K}_{2} \mathrm{HPO}_{4}$, $0.25 \mathrm{KH}_{2} \mathrm{PO}_{4}, 1.0 \mathrm{MgSO}_{4}, \mathrm{Ca}_{3}\left(\mathrm{PO}_{4}\right)_{2} 0.2,0.02 \mathrm{FeSO}_{4}, 0.005$ $\mathrm{H}_{3} \mathrm{BO}_{3}, 0.005\left(\mathrm{NH}_{4}\right)_{2} \mathrm{MoO}_{4}, 0.005 \mathrm{ZnSO}_{4} \cdot 7 \mathrm{H}_{2} \mathrm{O}, 0.002$ $\mathrm{MnSO}_{4}$ ] was added (Novikova and Safronova 1992). Seedlings were inoculated with individual strains or with a pair of strains isolated from the same nodule in the amount of $10^{6}$ cells of each strain per test tube. The uninoculated plants were used as negative control. Plants were cultivated for 5 weeks in the growth chamber with $50 \%$ relative humidity and four-level illumination/temperatures mode: night (dark, $18^{\circ} \mathrm{C}, 8 \mathrm{~h}$ ), morning $\left(200 \mu \mathrm{mol} \mathrm{m}{ }^{-2} \mathrm{~s}^{-1}, 20^{\circ} \mathrm{C}, 2 \mathrm{~h}\right)$, day $\left(400 \mu \mathrm{mol} \mathrm{m} \mathrm{s}^{-1}\right.$, $\left.23^{\circ} \mathrm{C}, 12 \mathrm{~h}\right)$, evening $\left(200 \mu \mathrm{mol} \mathrm{m} \mathrm{s}^{-1}, 20^{\circ} \mathrm{C}, 2 \mathrm{~h}\right)$. Illumination was performed by L 36W/77 Fluora lamps (Osram). The nodulation assay experiment was performed twice (preliminary and representative tests). The number of replicates in each treatment was two in the preliminary test and five in the representative test. At the end of the experiment, nodules were counted and the fresh biomass of plants (shoots plus roots) was determined. The nitrogen fixation of nodules was measured by the acetylene-reduction method (Turner and Gibson 1980), using a gas chromatograph GC-2014 (Shimadzu). Strains were re-isolated from the obtained nodules and were identified by 
16S rDNA sequencing as described above. Pictures of nodules were taken by the stereo microscope Stemi 508 (Carl Zeiss). The data were processed by the standard method of variance analysis using the Statistica version 10 software (StatSoft Inc.). Fisher's least significant difference test was used to evaluate differences between means.

\section{Whole-genome sequencing of the selected isolates.}

For whole-genome sequencing, strains $T$. robiniae $581, M$. loti 582, M. huakuii 583, Phyllobacterium sp. strain 628, and $R$. lusitanum 629 were selected. The whole genomes of six commercial rhizobia strains deposited in the RCAM collection and used as reference ( $R$. leguminosarum RCAM0610, RCAM0626, RCAM1365, and RCAM2802 and S. meliloti RCAM1115 and RCAM1750) were obtained previously (data not published). Genomic DNA was extracted using a Genomic DNA purification kit (Thermo Fisher Scientific) according to manufacturer recommendations. Long-read whole-genome sequencing was performed using a MinIon sequencer (Oxford Nanopore) of the Core Centrum "Genomic Technologies, Proteomics and Cell Biology" at the All-Russia Research Institute for Agricultural Microbiology. The SQK-LSK109 ligation sequencing kit with the EXP-NBD104 native barcoding expansion 1-12 kit was used to prepare the library according to manufacturer instructions. The reads were base-called and demultiplexed using the guppy_basecaller (v. 3.3.0). The Flye pipeline (v 2.6release) was used to assemble the Nanopore reads (Kolmogorov et al. 2019). The resulting assembly was corrected four times, using Racon (v1.3.2) (available online) with the following modifiers (-m $8-x-6-g-8-w 500)$, following with a single polish using the medaka ( $\mathrm{v} 0.10 .0)$ program with default parameters available online. A search for genes in the assembled contigs was performed using the RAST annotation service (Overbeek et al. 2014). All the genomes were assembled into circular replicons. Search for homologs of the symbiotic fix, nif, nod, noe, and nol genes as well as genes of the T3SS, T4SS, and T6SS secretion systems in annotated genomes was performed using CLC Genomics Workbench 7.5.1 software using local BLASTn and tBLASTx (available online).

\section{Accession numbers.}

All sequences have been deposited to the NCBI GenBank database. The whole-genome sequences are under accession numbers CP050292 for Tardiphaga robiniae 581, CP050293 to CP050295 for Mesorhizobium loti 582, CP050296 to CP050299 for M. huakuii 583, CP050300 to CP050303 for Phyllobacterium sp. strain 628, CP050304 to CP050308 for Rhizobium lusitanum 629, CP050549 to CP050552 for $R$. leguminosarum RCAM0610, CP050553 to CP050557 for R. leguminosarum RCAM0626, CP050514 to CP050519 for R. leguminosarum RCAM1365, CP050562 to CP050566 for R. leguminosarum RCAM2802, CP050558 to CP050561 for Sinorhizobium meliloti RCAM1115, and CP050511 to CP050513 for $S$. meliloti RCAM1750. Rrs sequences can be found under accession numbers MT192879 to MT225791.

\section{ACKNOWLEDGMENTS}

The authors thank T. Aksenova and T. Maslikova (All-Russia Research Institute for Agricultural Microbiology, St. Petersburg, Russia) for technical assistance.

\section{AUTHOR-RECOMMENDED INTERNET RESOURCES}

BLAST software: https://blast.ncbi.nlm.nih.gov Medaka (v 0.10.0): https://github.com/nanoporetech/medaka Racon (v1.3.2): https://github.com/lbcb-sci/racon

\section{LITERATURE CITED}

Ampomah, O. Y., Mousavi, S. A., Lindström, K., and Huss-Danell, K. 2017. Diverse Mesorhizobium bacteria nodulate native Astragalus and Oxytropis in arctic and subarctic areas in Eurasia. Syst. Appl. Microbiol. 40: 51-58.

Bingle, L. E., Bailey, C. M., and Pallen, M. J. 2008. Type VI secretion: A beginner's guide. Curr. Opin. Microbiol. 11:3-8.

Bonaldi, K., Gargani, D., Prin, Y., Fardoux, J., Gully, D., Nouwen, N., Goormachtig, S., and Giraud, E. 2011. Nodulation of Aeschynomene afraspera and A. indica by photosynthetic Bradyrhizobium sp. strain ORS285: The nod-dependent versus the nod-independent symbiotic interaction. Mol. Plant-Microbe Interact. 24:1359-1371.

Cascales, E., and Christie, P. J. 2003. The versatile bacterial type IV secretion systems. Nat. Rev. Microbiol. 1:137-149.

Chen, W. X., Li, G. S., Qi, Y. L., Wang, E. T., Yuan, H. L., and Li, J. L. 1991. Rhizobium huakuii sp. nov. isolated from the root nodules of Astragalus sinicus. Int. J. Syst. Bacteriol. 41:275-280.

De Meyer, S. E., Coorevits, A., and Willems, A. 2012. Tardiphaga robiniae gen. nov., sp. nov., a new genus in the family Bradyrhizobiaceae isolated from Robinia pseudoacacia in Flanders (Belgium). Syst. Appl. Microbiol. 35:205-214.

De Meyer, S. E., Tan, H. W., Andrews, M., Heenan, P. B., and Willems, A. 2016. Mesorhizobium calcicola sp. nov., Mesorhizobium waitakense $\mathrm{sp}$. nov., Mesorhizobium sophorae sp. nov., Mesorhizobium newzealandense sp. nov. and Mesorhizobium kowhaii sp. nov. isolated from Sophora root nodules. Int. J. Syst. Evol. Microbiol. 66:786-795.

De Meyer, S. E., and Willems, A. 2012. Multilocus sequence analysis of Bosea species and description of Bosea lupini sp. nov., Bosea lathyri sp. nov. and Bosea robiniae sp. nov., isolated from legumes. Int. J. Syst. Evol. Microbiol. 62:2505-2510.

Ghobakhlou, A.-F., Johnston, A., Harris, L., Antoun, H., and Laberge, S. 2015. Microarray transcriptional profiling of arctic Mesorhizobium strain N33 at low temperature provides insights into cold adaption strategies. BMC Genomics 16:383.

Han, T. X., Han, L. L., Wu, L. J., Chen, W. F., Sui, X. H., Gu, J. G., Wang, E. T., and Chen, W. X. 2008. Mesorhizobium gobiense sp. nov. and Mesorhizobium tarimense sp. nov., isolated from wild legumes growing in desert soils of Xinjiang, China. Int. J. Syst. Evol. Microbiol. 58: 2610-2618

Hou, B. C., Wang, E. T., Li, Y., Jia, R. Z., Chen, W. F., Man, C. X., Sui, X. H., and Chen, W. X. 2009. Rhizobial resource associated with epidemic legumes in Tibet. Microb. Ecol. 57:69-81.

Hubber, A., Vergunst, A. C., Sullivan, J. T., Hooykaas, P. J. J., and Ronson, C. W. 2004. Symbiotic phenotypes and translocated effector proteins of the Mesorhizobium loti strain R7A VirB/D4 type IV secretion system. Mol. Microbiol. 54:561-574.

Jarvis, B. D. W., Pankhurst, C. E., and Patel, J. J. 1982. Rhizobium loti, a new species of legume root nodule bacteria. Int. J. Syst. Bacteriol. 32: 378-380.

Jiang, G., and Krishnan, H. B. 2000. Sinorhizobium fredii USDA257, a cultivar-specific soybean symbiont, carries two copies of $y 4 y A$ and $y 4 y B$, two open reading frames that are located in a region that encodes the type III protein secretion system. Mol. Plant-Microbe Interact. 13:1010-1014.

Jiao, Y. S., Yan, H., Ji, Z. J., Liu, Y. H., Sui, X. H., Zhang, X. X., Wang, E. T., Chen, W. X., and Chen, W. F. 2015. Phyllobacterium sophorae sp. nov., a symbiotic bacterium isolated from root nodules of Sophora flavescens. Int. J. Syst. Evol. Microbiol. 65:399-406.

Knosel, D. H. 1984. Genus Phyllobacterium. Pages 254-256 in: Bergey's Manual of Systematic Bacteriology. N. R. Krieg, and J. G. Holt, eds. Vol. 1. The Williams \& Wilkins Co, Baltimore, MD, U.S.A.

Kolmogorov, M., Yuan, J., Lin, Y., and Pevzner, P. A. 2019. Assembly of long, error-prone reads using repeat graphs. Nat. Biotechnol. 37: 540-546.

Krishnan, H. B., Lorio, J., Kim, W. S., Jiang, G., Kim, K. Y., DeBoer, M., and Pueppke, S. G. 2003. Extracellular proteins involved in soybean cultivar-specific nodulation are associated with pilus-like surface appendages and exported by a type III protein secretion system in Sinorhizobium fredii USDA257. Mol. Plant-Microbe Interact. 16: 617-625.

Laguerre, G., van Berkum, P., Amarger, N., and Prévost, D. 1997. Genetic diversity of rhizobial symbionts isolated from legume species within the genera Astragalus, Oxytropis, and Onobrychis. Appl. Environ. Microbiol. 63:4748-4758.

Mantelin, S., Saux, M. F., Zakhia, F., Béna, G., Bonneau, S., Jeder, H. de Lajudie, P., and Cleyet-Marel, J.-C. 2006. Emended description of the genus Phyllobacterium and description of four novel species associated with plant roots: Phyllobacterium bourgognense sp. nov., 
Phyllobacterium ifriqiyense sp. nov., Phyllobacterium leguminum sp. nov. and Phyllobacterium brassicacearum sp. nov. Int. J. Syst. Evol. Microbiol. 56:827-839.

Martínez-Hidalgo, P., Ramírez-Bahena, M. H., Flores-Félix, J. D., Igual, J. M., Sanjuán, J., León-Barrios, M., Peix, A., and Velázquez, E. 2016. Reclassification of strains MAFF $303099^{\mathrm{T}}$ and R7A into Mesorhizobium japonicum sp. nov. Int. J. Syst. Evol. Microbiol. 66:4936-4941.

Martínez-Hidalgo, P., Ramírez-Bahena, M. H., Flores-Félix, J. D., Rivas, R., Igual, J. M., Mateos, P. F., Martínez-Molina, E., León-Barrios, M., Peix, Á., and Velázquez, E. 2015. Revision of the taxonomic status of type strains of Mesorhizobium loti and reclassification of strain USDA $3471 \mathrm{~T}$ as the type strain of Mesorhizobiumerdmanii sp. nov. and ATCC 33669T as the type strain of Mesorhizobiumjarvisii sp. nov. Int. J. Syst. Evol. Microbiol. 65:1703-1708.

Masson-Boivin, C., Giraud, E., Perret, X., and Batut, J. 2009. Establishing nitrogen-fixing symbiosis with legumes: How many rhizobium recipes? Trends Microbiol. 17:458-466.

Mergaert, J., Cnockaert, M. C., and Swings, J. 2002. Phyllobacterium myrsinacearum (subjective synonym Phyllobacterium rubiacearum) emend. Int. J. Syst. Evol. Microbiol. 52:1821-1823.

Mornico, D., Miché, L., Béna, G., Nouwen, N., Verméglio, A., Vallenet, D., Smith, A. A. T., Giraud, E., Médigue, C., and Moulin, L. 2012. Comparative genomics of Aeschynomene symbionts: Insights into the ecological lifestyle of nod-independent photosynthetic bradyrhizobia. Genes (Basel) 3:35-61.

Nelson, M. S., and Sadowsky, M. J. 2015. Secretion systems and signal exchange between nitrogen-fixing rhizobia and legumes. Front. Plant Sci. 6:491.

Notti, R. Q., and Stebbins, C. E. 2016. The structure and function of type III secretion systems. Microbiol. Spectr. 4.

Novikova, N., and Safronova, V. 1992. Transconjugants of Agrobacterium radiobacter harbouring sym genes of Rhizobium galegae can form an effective symbiosis with Medicago sativa. FEMS Microbiol. Lett. 93: 261-268.

Okazaki, S., Tittabutr, P., Teulet, A., Thouin, J., Fardoux, J., Chaintreuil, C., Gully, D., Arrighi, J. F., Furuta, N., Miwa, H., Yasuda, M., Nouwen, N., Teaumroong, N., and Giraud, E. 2016. Rhizobium-legume symbiosis in the absence of Nod factors: Two possible scenarios with or without the T3SS. ISME J. 10:64-74.

Overbeek, R., Olson, R., Pusch, G. D., Olsen, G. J., Davis, J. J., Disz, T., Edwards, R. A., Gerdes, S., Parrello, B., Shukla, M., Vonstein, V., Wattam, A. R., Xia, F., and Stevens, R. 2014. The SEED and the rapid annotation of microbial genomes using subsystems technology (RAST). Nucleic Acids Res. 42 (D1):D206-D214.

Paul, D., Kumar, R., Nanduri, B., French, T., Pendarvis, K., Brown, A., Lawrence, M. L., and Burgess, S. C. 2011. Proteome and membrane fatty acid analyses on Oligotropha carboxidovorans OM5 grown under chemolithoautotrophic and heterotrophic conditions. PLoS One 6: e17111.

Provorov, N. A. 2013. Improvement of symbiotic nitrogen fixation in plants: Molecular-genetic approaches and evolutionary models. Russ. J. Plant Physiol. 60:27-32.

Pueppke, S. G., and Broughton, W. J. 1999. Rhizobium sp. strain NGR234 and $R$. fredii USDA257 share exceptionally broad, nested host ranges. Mol. Plant-Microbe Interact. 12:293-318.

Russell, A. B., Peterson, S. B., and Mougous, J. D. 2014. Type VI secretion system effectors: Poisons with a purpose. Nat. Rev. Microbiol. 12: 137-148.

Safronova, V., Belimov, A., Sazanova, A., Chirak, E., Kuznetsova, I., Andronov, E., Pinaev, A., Tsyganova, A., Seliverstova, E., Kitaeva, A., Tsyganov, V., and Tikhonovich, I. 2019. Two broad host range rhizobial strains isolated from relict legumes have various complementary effects on symbiotic parameters of co-inoculated plants. Front. Microbiol. 10: 514.

Safronova, V., Belimov, A., Sazanova, A., Kuznetsova, I., Popova, J., Andronov, E., Verkhozina, A., and Tikhonovich, I. 2017. Does the Miocene-Pliocene relict legume Oxytropis triphylla form nitrogen-fixing nodules with a combination of bacterial strains? Int. J. Environ. Stud. 74:706-714.
Safronova, V. I., Belimov, A. A., Sazanova, A. L., Chirak, E. R., Verkhozina, A. V., Kuznetsova, I. G., Andronov, E. E., Puhalsky, J. V., and Tikhonovich, I. A. 2018a. Taxonomically different comicrosymbionts of a relict legume, Oxytropis popoviana, have complementary sets of symbiotic genes and together increase the efficiency of plant nodulation. Mol. Plant-Microbe Interact. 31:833-841.

Safronova, V. I., Kuznetsova, I. G., Sazanova, A. L., Kimeklis, A. K., Belimov, A. A., Andronov, E. E., Pinaev, A. G., Chizhevskaya, E. P., Pukhaev, A. R., Popov, K. P., Willems, A., and Tikhonovich, I. A. 2015. Bosea vaviloviae sp. nov., a new species of slow-growing rhizobia isolated from nodules of the relict species Vavilovia formosa (Stev.) Fed. Antonie van Leeuwenhoek 107:911-920.

Safronova, V. I., Sazanova, A. L., Kuznetsova, I. G., Belimov, A. A., Andronov, E. E., Chirak, E. R., Popova, J. P., Verkhozina, A. V., Willems, A., and Tikhonovich, I. A. 2018b. Phyllobacterium zundukense sp. nov., a novel species of rhizobia isolated from root nodules of the legume species Oxytropis triphylla (Pall.) Pers. Int. J. Syst. Evol. Microbiol. 68: 1644-1651.

Sánchez, M., Ramírez-Bahena, M. H., Peix, A., Lorite, M. J., Sanjuán, J., Velázquez, E., and Monza, J. 2014. Phyllobacterium loti sp. nov. isolated from nodules of Lotus corniculatus. Int. J. Syst. Evol. Microbiol. 64: 781-786.

Sprent, J. I. 2001. Nodulation in legumes. Royal Botanical Gardens, Kew, U.K.

Streit, W. R., Schmitz, R. A., Perret, X., Staehelin, C., Deakin, W. J., Raasch, C., Liesegang, H., and Broughton, W. J. 2004. An evolutionary hot spot: The pNGR234b replicon of Rhizobium sp. strain NGR234. J. Bacteriol. 186:535-542.

Sugawara, M., Epstein, B., Badgley, B. D., Unno, T., Xu, L., Reese, J., Gyaneshwar, P., Denny, R., Mudge, J., Bharti, A. K., Farmer, A. D., May, G. D., Woodward, J. E., Médigue, C., Vallenet, D., Lajus, A., Rouy, Z., Martínez-Vaz, B., Tiffin, P., Young, N. D., and Sadowsky, M. J. 2013. Comparative genomics of the core and accessory genomes of 48 Sinorhizobium strains comprising five genospecies. Genome Biol. 14: R17.

Tampakaki, A. P. 2014. Commonalities and differences of T3SSs in rhizobia and plant pathogenic bacteria. Front. Plant Sci. 5:114.

Tamura, K., Peterson, D., Peterson, N., Stecher, G., Nei, M., and Kumar, S. 2011. MEGA5: Molecular evolutionary genetics analysis using maximum likelihood, evolutionary distance, and maximum parsimony methods. Mol. Biol. Evol. 28:2731-2739.

Turner, G. L., and Gibson, A. H. 1980. Measurement of nitrogen fixation by indirect means. Pages 111-138 in: Methods for Evaluating Biological Nitrogen Fixation. F. J. Bergensen, ed. Wiley, Toronto, Canada.

Valverde, A., Velázquez, E., Fernández-Santos, F., Vizcaíno, N., Rivas, R., Mateos, P. F., Martínez-Molina, E., Igual, J. M., and Willems, A. 2005. Phyllobacterium trifolii sp. nov., nodulating Trifolium and Lupinus in Spanish soils. Int. J. Syst. Evol. Microbiol. 55:1985-1989.

Vincent, J. M. 1970. A manual for the practical study of root nodule bacteria. Pages 73-97 in: IBP Handbook. Blackwell Scientific Publications, Oxford.

Weidner, S., Becker, A., Bonilla, I., Jaenicke, S., Lloret, J., Margaret, I., Pühler, A., Ruiz-Sainz, J. E., Schneiker-Bekel, S., Szczepanowski, R., Vinardell, J. M., Zehner, S., and Göttfert, M. 2012. Genome sequence of the soybean symbiont Sinorhizobium fredii HH103. J. Bacteriol. 194: 1617-1618.

Weisburg, W. G., Barns, S. M., Pelletier, D. A., and Lane, D. J. 1991. 16S ribosomal DNA amplification for phylogenetic study. J. Bacteriol. 173: 697-703.

Xu, L., Zhang, Y., Deng, Z. S., Zhao, L., Wei, X. L., and Wei, G. H. 2013. Rhizobium qilianshanense sp. nov., a novel species isolated from root nodule of Oxytropis ochrocephala Bunge in China. Antonie van Leeuwenhoek 103:559-565.

Zheng, W. T., Li, Y., Jr., Wang, R., Sui, X. H., Zhang, X. X., Zhang, J. J., Wang, E. T., and Chen, W. X. 2013. Mesorhizobium qingshengii sp. nov., isolated from effective nodules of Astragalus sinicus. Int. J. Syst. Evol. Microbiol. 63:2002-2007. 